Тел.: +79375232490

Шакиров Шамиль Касымович, $\partial-p c$.- $x$. наук, проф., главный научный сотрудник отдела агробиологических исследований, ТатНИИСХ ФИЦ КазНЦ РАН. Россия.

420059, г. Казань, ул. Оренбургский тракт, 48.

Тел.: + 79172697645 .

Ахметзянова Фирая Казбековна, $\partial-p$ биол. наук, проф., зав. кафедрой «Кормление», ФГБОУ ВО Казанская ГАВМ. Россия.
420029, г. Казань, ул. Сибирский тракт, 35.

Тел.: + 79050265486 .

Шарафутдинов Газимзян Салимович, $\partial-p c$. - . наук, проф. кафедры «Биотехнология, животноводство и химия», ФГБОУ ВО Казанский ГАУ. Россия.

420015, г. Казань, ул. К. Маркса, 65.

Тел.: + 79196851089 .

Ключевые слова: комбикорма; энергетический концентрат «Цеолфат»; корова; молоко.

\title{
EXPERIMENTAL ENERGY CONCENTRATE “ZEOLFAT” IN THE DIETS OF LACTATING COWS
}

Kashaeva Alia Rinatovna, Candidate of Biological Sciences, Associate Professor of the chair "Feeding", Kazan State Academy of Veterinary Medicine named after N.E. Bauman. Russia.

Shakirov Shamil Kasymovich, Doctor of Agricultural Sciences, Professor, Chief Researcher, Tatar Research Institute of Agriculture - Subdivision of the Federal Research Center "Kazan Scientific Center of Russian Academy of Sciences". Russia.

Akhmetzyanova Firaya Kazbekovna, Doctor of Biological Sciences, Professor, Head of the chair "Feeding", Kazan State Academy of Veterinary Medicine named after N.E. Bauman. Russia.

Sharafutdinov Gazimzyan Salimovich, Doctor of Agricultural Sciences, Professor of the chair "Biotechnology, Livestock Breeding and Chemistry”, Kazan State Agrarian University. Russia.

Keywords: mixed fodder; energy concentrate "Zeolfat"; cow; milk.
The introduction of the experimental energy concentrate "Zeolfat" in doses of 200, 400 and $600 \mathrm{~g} / \mathrm{kg}$ per day into the main diet of lactating cows allowed increasing the content of raw fat by $6.69 \%, 13.38 \%$ and $19.91 \%$; exchanging energy by 1.46; 2.92 and $4.37 \%$, respectively. As a result, the increase in average daily milk yields in terms of (3.4\%) basic fat content was $8.1 \%$ in the I group with the introduction of $200 \mathrm{~g}$ of concentrate, in the II (400 $\mathrm{g})-13.7$, in the III $(600 \mathrm{~g})-14.3 \%$ compared to the control. A positive effect on the biochemical parameters of blood serum characterizing carbohydrate-lipid and mineral metabolism in the body was established. Economic efficiency per 1 RUB of additional costs in the experimental groups was 2.83-5.53 RUB, respectively.

DOI 10.28983/asj.y2020i6pp62-66

удк 636.085.553

\section{ОБУСЛОВЛЕННОСТЬ АМИНОКИСЛОТНОГО СОСТАВА ЭКСПЕРИМЕНТАЛЬНЫХ ОБРАЗЦОВ КОМБИКОРМА ДЛЯ МОЛОДНЯКА КРС}

\begin{abstract}
КИБКАЛО Илья Анатольевич, ФГБНУ Российский научно-исследовательский и проектно-технологический институт сорго и кукурузы «Россорго»

КАМЕНЕВА Ольга Борисовна, ФГБНУ Российский научно-исследовательский и проектно-технологический институт сорго и кукурузы «Россорго»
\end{abstract}

ЖУк Екатерина Александровна, ФГБНУ Российский научно-исследовательский и проектно-технологический институт сорго и кукурузы «Россорго»

БЫЧковА Вера Валерьевна, ФГБНУ Российский научно-исследовательский и проектно-технологический институт сорго и кукурузы «Россорго»

Проанализирован аминокислотный состав протеина в образиах комбикормов экспериментальных рецептур для молодняка КРС. Выявлена вариация содержания отдельных аминокислот в зависимости от компонентного состава комбикорма. Рассмотрены возможности совмещения высокого содержания отдельных незаменимых аминокислот в одном варианте комбикорма.

Введение. Развитие животноводства - одно из базовых и перспективных направлений модернизации сельскохозяйственной отрасли Российской Федерации. Успехи в этом направлении невозможны без создания мощной кормовой базы. Поэтому поиск наиболее эффективных

вариантов кормления сельскохозяйственных животных заслуженно находится в тренде развития сельскохозяйственной науки [4]. Ранее нами [9] были проанализированы экспериментальные образцы комбикормов для молодняка КРС с участием сорго зернового, актуального для засушливых регионов страны [3, 7], с позиции их энергетической эффективности. Однако их питательность с точки зрения сбалансированности аминокислотного состава белка - не менее важная характеристика ценности корма [5]. Концепция «идеального протеина» (сбалансированного по аминокислотному составу) воспринимается большинством исследователей как наиболее прогрессивная в сравнении с идеей количественного насыщения кормов протеином [8].

Цель исследований - проанализировать сбалансированность аминокислотного состава 
экспериментальных образцов комбикорма в зависимости от его состава.

Методика исследований. Экспериментальные комбикорма-концентраты (КК) для молодняка КРС (с 6 до 18 месяцев) были получены путем грубого помола зерна и семян следующих культур: пшеницы озимой (сорт Касатка), ячменя (сорт Нутанс 553), кукурузы (сорт РНИИСК), сорго зернового (сорт Аванс), тритикале (сорт Орлик), нута (сорт Бонус), сои (сорт Марина), чины (сорт Мраморная), амаранта (сорт Полет), а также жмыха подсолнечного.

Рецепты комбикормов разработаны на основе современных научных данных потребности организма животного с учетом данного вида и возраста. Составленные рецепты соответствуют комбикормам марки КК-63 (ГОСТ 9268-2015). Комбикорма марки КК-63 используются в составе рациона молодняка жвачных, после завершения формирования рубцового пищеварения, с возраста более 120 дней, заканчивается их применение откормом или переводом животных в группу телок [1, 6].

Всего было оценено 10 вариантов смесей комбикормов-концентратов [9]. Во всех вариантах содержание зерновых компонентов составляло 70 \% (пшеница, ячмень, сорго, кукуруза), зернобобовых культур (нут, соя, чина) - 2-10 \%, подсолнечного жмыха $-12-15 \%$, амаранта $-0-5 \%$. В экспериментальных образцах предполагалось снизить долю традиционных зерновых за счет увеличения зерна сорго. Таким образом, содержание зерна пшеницы варьировало от 0 до 25 \%, сорго - 0-35\%, ячменя - 0-25\%, кукурузы 0-20\%, тритикале - 0-10\%.

Аминокислотный состав протеина комбикормов анализировали на инфракрасном анализаторе фирмы Foss.

Статистическую обработку данных проводили по методике Б.А. Доспехова [2] с использованием программы Agros, версии 2.09 статистического и биометрико-генетического анализа в растениеводстве и селекции.

Результаты исследований. Анализ аминокислотного состава комбикормовых смесей позволил рассчитать их процентное содержание в суммарном сыром белке корма, определить фактическую вариацию этого содержания, обусловленную составом смеси, а также вариацию, выраженную в процентах от среднего значения содержания каждой аминокислоты по опыту (табл. 1).

Полученные данные показали, что в среднем аминокислотный состав варьировал на 15 \% в зависимости от состава корма. Самый высокий по опыту коэффициент вариации $(\mathrm{CV})$ оказался у глютолина. При этом по фактической величине наиболее подвергалось изменению содержание глютолина, аргинина, аспартата. Наименее всего был подвержен вариации триптофан. Вариация, выраженная в процентах от среднего значения каждой аминокислоты по опыту, показала, что наиболее подвержены влиянию в составе ком- бикорма метионин, цистеин, аспартат, аргинин, глютолин (17,3-28,6 \%); наименее всего - триптофан, лейцин, валин, тирозин (6,8-10,2 \%).

Корреляционный анализ позволил установить взаимосвязь процентного содержания компонентов кормосмесей с содержанием некоторых аминокислот в протеине корма (табл. 2). Выяснилось, что статистически доказанное положительное влияние имела процентная доля в комбикорме пшеницы на содержание цистеина, пролина, триптофана, глютолина. На уровне тенденции можно предположить ее негативное влияние на содержание аспартата, лизина, треонина.

Привнесение в кормосмесь сорго положительно влияло на содержание аспартата и на уровне тенденции на содержание аргинина, серина, лизина, треонина, тирозина; отрицательно - глютолина, цистеина, метионина, на уровне тенденции - триптофана. Содержание в корме сои значимо влияло на повышение доли аргинина, аспартата, лизина, треонина и на уровне тенденции - аланина, глицина, изолейцина, фенилаланина, серина, тирозина; отрицательно - глютолина, цистеина, триптофана и на уровне тенденции - метионина, пролина.

Добавление амаранта повышало содержание тирозина, на уровне тенденции - аргинина, аспартата, глицина, лейцина, финилаланина, пролина, серина. Отрицательно сказывалось на уровне тенденции содержание метионина. Привнесение зерна тритикале отрицательно сказывалось на содержании тирозина, на уровне тенденции - лизина, серина, триптофана; положительно на уровне тенденции - цистеина, метионина. Coдержание подсолнечного жмыха положительно связывалось с содержанием аспартата, на уровне тенденции - аргинина, изолейцина, лейцина, фенилаланина, треонина; отрицательно на уровне тенденции - цистеина. Добавление в комбикорм нута положительно сказывалось на уровне тенденции на содержании гистидина, изолейцина, лейцина, лизина, финилаланина, треонина, тирозина; ячменя - цистеина, метионина, триптофана. Последний отрицательно влиял на уровне тенденции на содержание аспартата, тирозина.

Наименьшее влияние на аминокислотный состав оказывала доля присутствия в комбикорме кукурузы и чины, что можно объяснить как большей сбалансированностью содержания аминокислот, которое приближалось к средним значениям по опыту (кукуруза), так и недостаточностью вариантов смешивания (чина). Наименее подверженными влиянию компонентного состава комбикорма оказались аланин, гистидин и валин.

Также по корреляционному анализу заметны антагонистические взаимоотношения в смесях, с одной стороны, пшеницы, в одну группу с которой можно отнести ячмень и тритикале, с другой - сои и сорго, в одну группу с которыми можно отчасти отнести амарант и подсолнечный жмых. Проявляется это противодействие в усилении и ослаблении присутствия в смесях определенных аминокислот. Так, первая группа культур в основном положитель- 


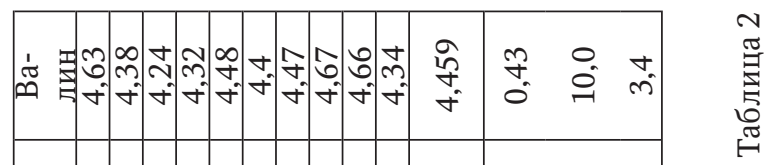

至 $\Rightarrow m m m m m m m m m m m$

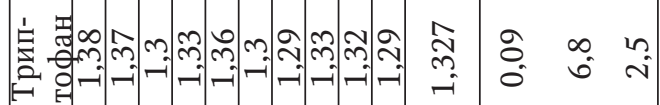

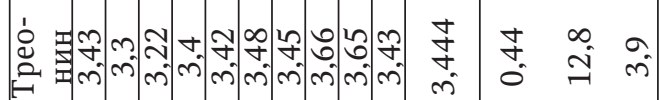

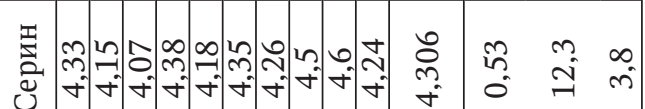

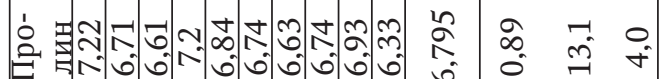

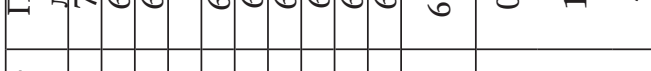

寊 它

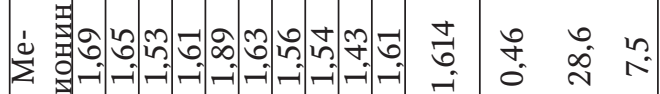

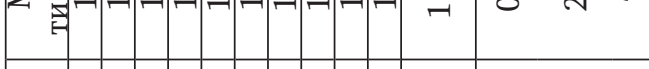

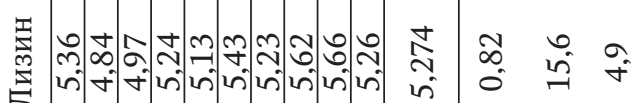

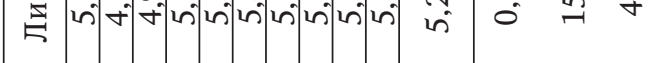

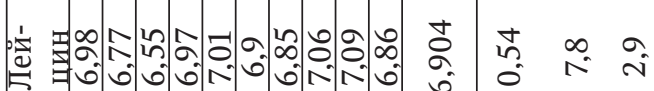

\begin{tabular}{lll}
\hline & 0 \\
\hline
\end{tabular}

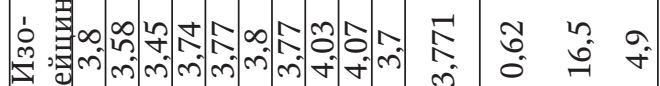
a m m m m

离

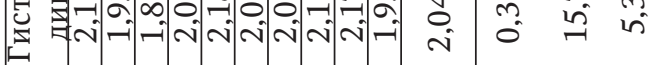

ร月ำ

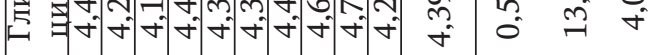

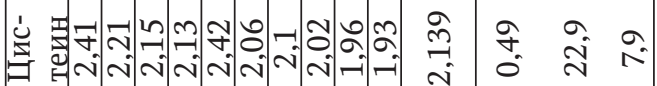

ש nd N

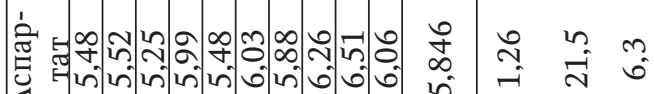

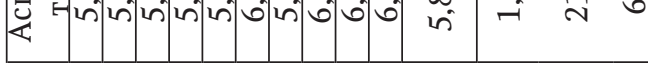

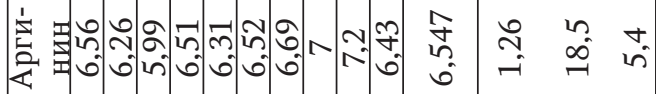

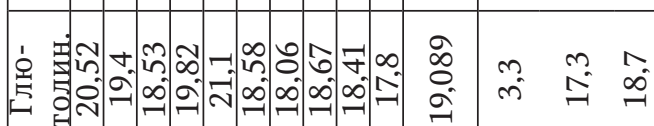

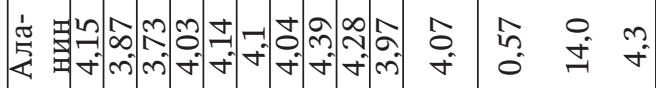

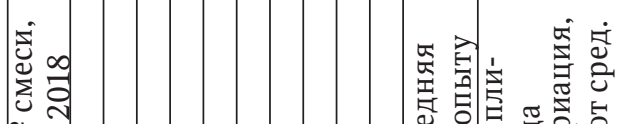

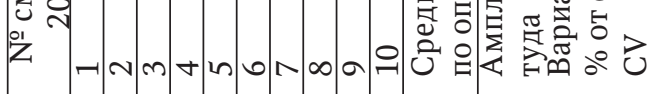

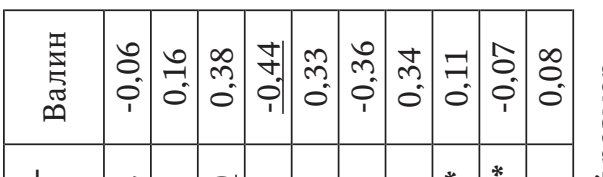

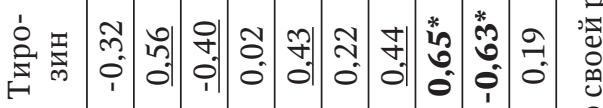

竞壳

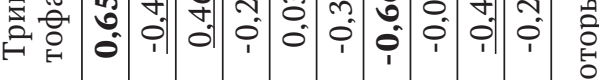

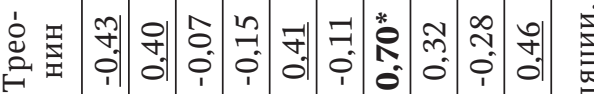

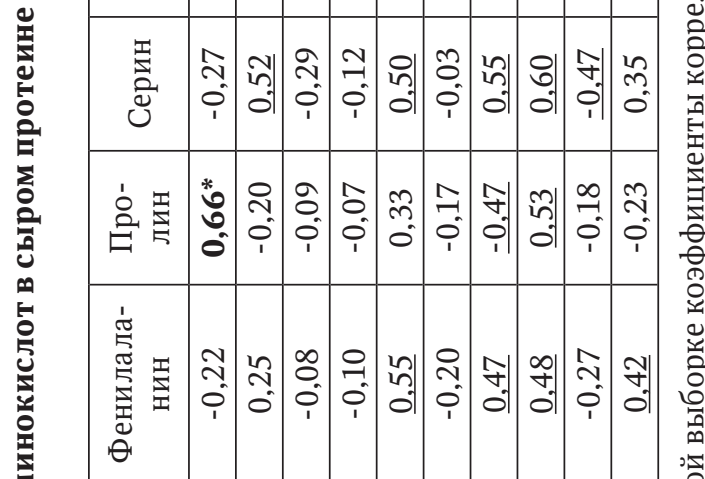

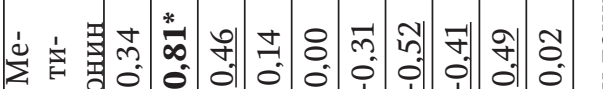

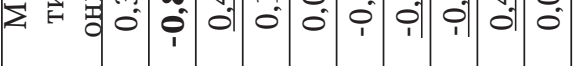

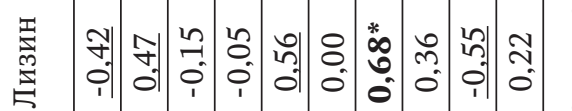

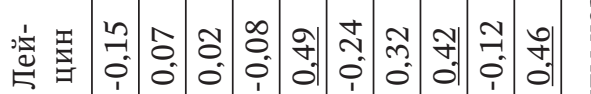

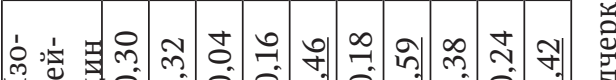

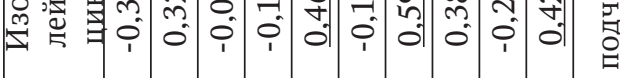

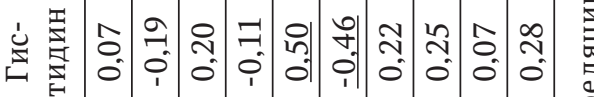

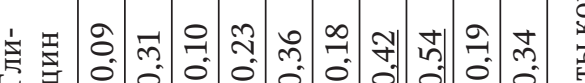

E⿱

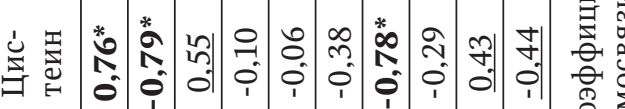

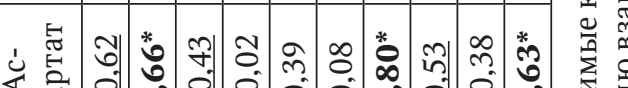

《萣

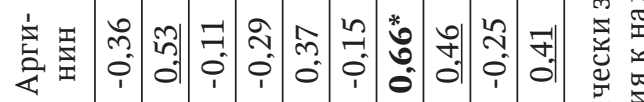

定

至

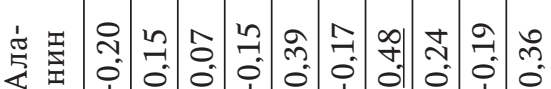

西总

淧

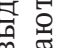

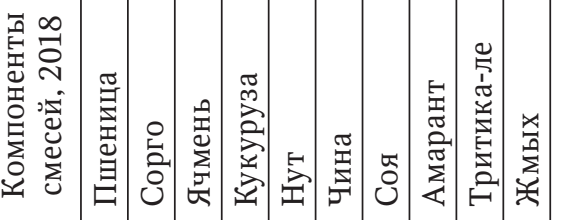


но влияла на содержание в корме глютолина, цистеина, метионина, триптофана и отрицательно - на содержание аспартата, лизина, серина, треонина, тирозина. Вторая группа компонентов обладала противоположным воздействием на перечисленные аминокислоты.

Анализ данных содержания аминокислот в комбикормах в целом подтвердил выявленные тенденции на уровне сырого протеина (табл. 3). При этом следует отметить, что содержание в корме большинства изученных аминокислот имело тесную положительную взаимосвязь с содержанием в нем сырого протеина. Исключение составили только глютолин и метионин. Это, а также тот факт, что содержание цистеина имело значимую отрицательную сопряженность с содержанием белка, а большинство положительно связанных с ним аминокислот сохранило значимую сопряженность и с процентным содержанием в корме сои, говорит о том, что основная вариация содержания сырого протеина в опытных образцах, как и указанных аминокислот, связана именно с привнесением соевого компонента. Исключение составил только лейцин, высокозначимо связанный с белковостью $\left(0,91^{*}\right)$, но не зависимый от содержания в корме сои.

Выявленные на уровне сырого протеина антагонистические тенденции между группами аминокислот и между компонентами, усиливающими содержание их в корме, на уровне вариантов комбикорма стали еще заметнее (см. табл. 3). Таким образом, представляется сомнительным вариант обеспечения животных необходимыми аминокислотами путем увеличения белковости корма. Актуальной представляется идея сбалансированности содержания аминокислот между собой в белке комбикорма или концепция «идеального протеина» [8]. По корреляционному анализу содержания аминокислот в протеине комбикорма между собой, хотя они и не находились в доказанном антагонизме (кроме пары аспартат-цистеин, $r=-0,76^{*}$ ), но по высокозначимой положительной сопряженности, дополненной в ряде случаев сопряженностью среднего уровня $\left(0,54-0,97^{*}\right)$, распределялись на группы: 1-я - аланин, аргинин, аспартат, глицин, гистидин, изолейцин, лейцин, лизин, финилаланин, сирин, треонин, тирозин, валин; 2-я - глютолин, метионин, цистеин, пролин, триптофан.

При составлении кормовых смесей особое внимание следует уделять сбалансированности по незаменимым аминокислотам, достаточное количество которых в корме обязательно [5]. К таковым относятся гистидин, изолейцин, лейцин, лизин, метионин, фенилаланин, треонин, триптофан, валин. По нашим данным, совмещение их максимальных значений в одной кормосмеси - непростая задача. Часть из них попадает в одну группу (метионин, триптофан), на вариацию которой в целом оказывает положительное влияние внесение зерна колосовых злаков (ячмень, пшеница, тритикале), другая (гистидин, изолейцин, лейцин, лизин, фенилаланин, треонин, валин) - испытывает положительное влия-

\begin{tabular}{|c|c|c|c|c|c|c|c|c|c|c|c|}
\hline 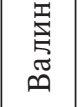 & $\begin{array}{l}\stackrel{+}{+}^{+} \\
0 \\
0\end{array}$ & $\left|\begin{array}{l}\text { 임 } \\
0 \\
0\end{array}\right|$ & -1) & \begin{tabular}{l|l}
$n$ & 0 \\
0 & \\
0 & 1
\end{tabular} & 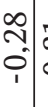 & & $\begin{array}{l}1 \\
0 \\
0 \\
0 \\
1\end{array}$ & $\begin{array}{c}\stackrel{*}{*} \\
\infty \\
0 \\
0\end{array}$ & की & 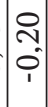 & m. \\
\hline 点 & $\begin{array}{l}\hat{N}^{*} \\
0 \\
0\end{array}$ & $\left|\begin{array}{c}* \\
0 \\
0 \\
0 \\
1 \\
1\end{array}\right|$ & \begin{tabular}{|c|}
$*$ \\
$N$ \\
$N$ \\
0 \\
0
\end{tabular} & 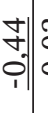 & 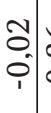 & & 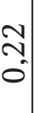 & $\begin{array}{c}\text { *a. } \\
\infty \\
0 \\
0\end{array}$ & พั. & $\mid \begin{array}{l}\infty \\
+ \\
0 \\
1\end{array}$ & ㅇ. \\
\hline 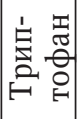 & $\begin{array}{l}* \\
0 \\
\infty \\
0 \\
0\end{array}$ & $\mid \begin{array}{l}1 \\
\text { nn } \\
0 \\
1\end{array}$ & $\mid$\begin{tabular}{|}
$*$ \\
\multirow{2}{*}{} \\
0 \\
0
\end{tabular} & 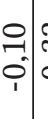 & $\begin{array}{l}N \\
\text { ñ } \\
0 \\
\end{array}$ & & $\begin{array}{l}1 \\
0 \\
0 \\
1\end{array}$ & \begin{tabular}{l}
$*$ \\
\multirow{2}{*}{} \\
$\infty$ \\
0 \\
0
\end{tabular} & ?. & \begin{tabular}{l}
$\mathcal{1}$ \\
\hdashline \\
\\
1
\end{tabular} & पे \\
\hline 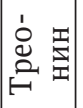 & $\stackrel{*}{\sigma}$ & $\left|\begin{array}{c}* \\
\infty \\
0 \\
0 \\
0 \\
1\end{array}\right|$ & $\mid$ & 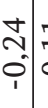 & 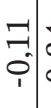 & & $\begin{array}{l}n \\
0 \\
0 \\
0\end{array}$ & ڤ్ & $\begin{array}{l}\stackrel{m}{N} \\
0\end{array}$ & $\mid$\begin{tabular}{l}
$\infty$ \\
$N$ \\
\hdashline \\
0 \\
1
\end{tabular} & 㫌 \\
\hline 崩 & $\begin{array}{l}* \\
\infty \\
\infty \\
0 \\
0\end{array}$ & ్ㅔ & 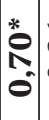 & \begin{tabular}{l|l}
0 \\
$m$ \\
0 \\
0
\end{tabular} & \begin{tabular}{l|l}
0 \\
:- \\
0 \\
\end{tabular} & & $\begin{array}{l}\infty \\
0 \\
0 \\
0\end{array}$ & \begin{tabular}{c}
\multirow{2}{*}{} \\
$\infty$ \\
0 \\
0 \\
0
\end{tabular} & ले & $\mid \begin{array}{l}\infty \\
m \\
0 \\
1\end{array}$ & ำ \\
\hline 竞 & ถิ. & 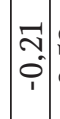 & 命 & 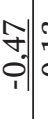 & $\begin{array}{lll}m & \\
7 \\
0 \\
1\end{array}$ & & $\begin{array}{l}-1 \\
0 \\
0 \\
0\end{array}$ & 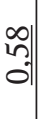 & $\begin{array}{l}0 \\
0 \\
0 \\
0 \\
0\end{array}$ & $\begin{array}{l}7 \\
\overrightarrow{0} \\
0 \\
1\end{array}$ & $\begin{array}{c}\hat{n} \\
0 \\
0\end{array}$ \\
\hline 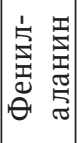 & $\begin{array}{l}* \\
\text { in } \\
\infty \\
0 \\
0\end{array}$ & $\mid$\begin{tabular}{c}
$*$ \\
\multirow{6}{6}{} \\
0 \\
1 \\
1
\end{tabular} & 메 & \begin{tabular}{l|l}
$\hat{N}$ & \\
0 \\
1
\end{tabular} & \begin{tabular}{l|l}
0 \\
0 \\
0 \\
0
\end{tabular} & & $\begin{array}{l}-1 \\
0 \\
0 \\
1\end{array}$ & $\begin{array}{l}* \\
\infty \\
\infty \\
0 \\
0\end{array}$ & $\begin{array}{l}\tilde{n} \\
\tilde{m} \\
0\end{array}$ & $\begin{array}{l}0 \\
n \\
0 \\
1\end{array}$ & 贶: \\
\hline 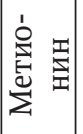 & ने & $\mid \begin{array}{l}0 \\
-1 \\
0 \\
1\end{array}$ & $\mid$ & $\begin{array}{c}m \\
m \\
0\end{array}$ & $\begin{array}{l} \pm \\
\\
0\end{array}$ & & $\begin{array}{l}\text { ר్ } \\
\text { on } \\
1\end{array}$ & 今. & . & ? & 文 \\
\hline 奈 & $\begin{array}{l}* 0 \\
\infty \\
\infty \\
0 \\
0\end{array}$ & $\left|\begin{array}{c}* \\
\multirow{2}{0}{} \\
0 \\
0 \\
0 \\
1\end{array}\right|$ & \begin{tabular}{l}
$*$ \\
\multirow{6}{0}{} \\
0 \\
0 \\
0
\end{tabular} & 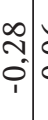 & $\begin{array}{ll}0 \\
0 \\
0 \\
1 & \\
1 & \end{array}$ & & $\begin{array}{l}\hat{\sigma} \\
\text { o. } \\
0\end{array}$ & 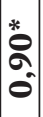 & $\begin{array}{l}\infty \\
\text { N } \\
0\end{array}$ & 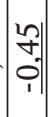 & ฯै. \\
\hline 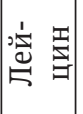 & बै & 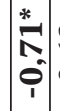 & 김 & 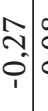 & $\begin{array}{l}\infty \\
0 \\
0 \\
0 \\
1\end{array}$ & & $\begin{array}{l} \pm \\
0 \\
0 \\
0\end{array}$ & $\begin{array}{c}\infty \\
\stackrel{2}{0} \\
0\end{array}$ & 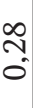 & 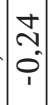 & "ే \\
\hline 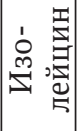 & $\begin{array}{l}\stackrel{*}{\infty} \\
\stackrel{\infty}{0}\end{array}$ & 멤 & 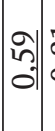 & 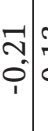 & \begin{tabular}{lll}
$m$ & \\
\hdashline \\
0 \\
1
\end{tabular} & & $\begin{array}{l}0 \\
0 \\
0 \\
1\end{array}$ & $\begin{array}{c}* \\
\infty \\
\infty \\
0 \\
0\end{array}$ & $\begin{array}{l}0 \\
\text { ñ } \\
0\end{array}$ & $\mid \begin{array}{l}1 \\
\hat{n} \\
0 \\
1\end{array}$ & 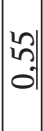 \\
\hline 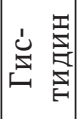 & $\begin{array}{l}\hat{N}_{0}^{*} \\
0\end{array}$ & 辛 & $\mid \begin{array}{c}N \\
\\
0\end{array}$ & \begin{tabular}{l|l}
$\infty$ & \\
0 & \\
0 & 1
\end{tabular} & \begin{tabular}{l}
7 \\
\hdashline \\
1 \\
1
\end{tabular} & \begin{tabular}{l}
0 \\
\multirow{+}{*}{} \\
0 \\
0
\end{tabular} & $\begin{array}{l}\text { ñ. } \\
\text { on } \\
1\end{array}$ & $\begin{array}{l}* \\
\infty \\
1 \\
0 \\
0\end{array}$ & సิ & $\mid$\begin{tabular}{c}
0 \\
\hdashline \\
0 \\
1
\end{tabular} & $\begin{array}{l}10 \\
n \\
0\end{array}$ \\
\hline 壳惫 & $\begin{array}{l}\stackrel{+}{+}^{\circ} \\
0\end{array}$ & 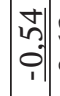 & 징| & \begin{tabular}{lll}
$\widehat{N}$ & 1 \\
0 \\
\hdashline
\end{tabular} & 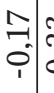 & $\begin{array}{c}\tilde{m} \\
\tilde{\sigma}\end{array}$ & $\begin{array}{l}-1 \\
0 \\
0 \\
1\end{array}$ & $\begin{array}{c}* \\
\tilde{n} \\
\infty \\
0 \\
0\end{array}$ & $\begin{array}{l}\infty \\
\text { ñ } \\
0\end{array}$ & {$\left[\begin{array}{l}2 \\
2 \\
0 \\
1\end{array}\right.$} & ㄱ․ \\
\hline 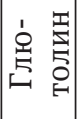 & ?ֶ. & $\mid \begin{array}{l}\stackrel{n}{2} \\
\stackrel{2}{0} \\
0\end{array}$ & ๆ̂. & $\begin{array}{ll}\text { I. } \\
0 \\
0\end{array}$ & ־.: & $\begin{array}{l}\stackrel{+}{\sim} \\
\vdots \\
0\end{array}$ & \begin{tabular}{l}
0 \\
\multirow{2}{*}{} \\
0 \\
1
\end{tabular} & $\begin{array}{l}+ \\
0 \\
0 \\
1 \\
1\end{array}$ & 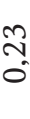 & స్త. & $\stackrel{+}{f}$ \\
\hline 总 & $\begin{array}{l}\text { in } \\
\text { in } \\
0 \\
0 \\
1\end{array}$ & $\mid$\begin{tabular}{|c|}
$*$ \\
\multirow{్}{*}{} \\
0 \\
0
\end{tabular} & $\mid \begin{array}{c}* \\
n \\
N \\
0 \\
1 \\
1\end{array}$ & 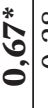 & 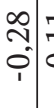 & \begin{tabular}{l}
-1 \\
\hdashline \\
0 \\
\end{tabular} & $\begin{array}{l}0 \\
\stackrel{2}{2} \\
0 \\
1\end{array}$ & $\begin{array}{c}0 \\
q \\
0 \\
0\end{array} \mid$ & $\begin{array}{l}0 \\
+ \\
\text { +o } \\
\text { î }\end{array}$ & $\mid \begin{array}{l}* \\
\tilde{n} \\
\tilde{\sigma} \\
0 \\
0\end{array}$ & 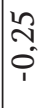 \\
\hline 总 & $\frac{*}{\sigma}$ & 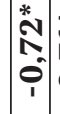 & $\begin{array}{c}* \\
N^{*} \\
0\end{array}$ & 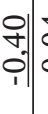 & \begin{tabular}{l|l}
1 & 0 \\
0 \\
0 \\
0 \\
1
\end{tabular} & $\begin{array}{c}\widehat{N} \\
\text { O. }\end{array}$ & 경 & $\mid \begin{array}{l}* \\
0 \\
\infty \\
0 \\
0 \\
0\end{array}$ & ले & ?. & 豆 \\
\hline 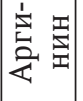 & $\begin{array}{l}\hat{A}^{*} \\
\infty \\
0\end{array}$ & 메 & $\mid$ & \begin{tabular}{l|l} 
& \\
& \\
0 & \\
1 &
\end{tabular} & 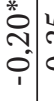 & $\begin{array}{l}\mathfrak{n} \\
\\
0\end{array}$ & $\begin{array}{l}-1 \\
0 \\
0 \\
1\end{array}$ & $\mid \begin{array}{l}* \\
\infty \\
\infty \\
0 \\
0\end{array}$ & mे & \begin{tabular}{l}
0 \\
\multirow{2}{*}{} \\
0 \\
1
\end{tabular} & 드. \\
\hline 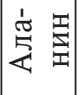 & $\begin{array}{l}\frac{*}{\infty} \\
0 \\
0\end{array}$ & |이 & 诘 & $\begin{array}{l}0 \\
0 \\
0 \\
0 \\
1\end{array}$ & \begin{tabular}{l|l} 
\pm & 0 \\
\hdashline \\
\hdashline \\
1
\end{tabular} & $\begin{array}{c}\infty \\
\underset{N}{\infty} \\
\vdots\end{array}$ & $\begin{array}{l}\text { ON} \\
0 \\
0 \\
1\end{array}$ & $\mid \begin{array}{c}* \\
2 \\
\infty \\
0 \\
0 \\
0\end{array}$ & \begin{tabular}{c}
$\infty$ \\
\multirow{2}{0}{} \\
0
\end{tabular} & 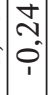 & 苟. \\
\hline 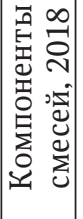 & 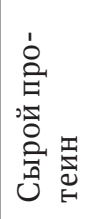 & 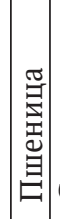 & 임. & 弆: & 常 & 穿 & 茎 & نِ & 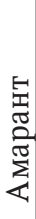 & 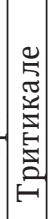 & 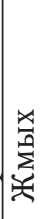 \\
\hline
\end{tabular}


ние содержания сои, сорго и некоторых других компонентов комбикорма. Обе группы имеют тенденцию к антагонизму.

Заключение. Лимитирующими незаменимыми аминокислотами для молодняка КРС принято считать метионин, лизин и треонин. Увеличение в комбикорме процентной доли сои и сорго за счет сокращения доли колосовых зерновых положительно сказывается на содержании в нем лизина и треонина, а также, как показано нами ранее, увеличивает энергетическую ценность корма. Однако имеет явную тенденцию на сокращение содержания метионина. Кроме того, метионин из всех аминокислот имеет самую большую вариацию в зависимости от состава комбикорма - до 28,6 \% от своего среднего значения по опыту при 12,8-15,6 \% у лизина и треонина. Таким образом, именно содержание метионина нуждается в стабилизации.

При увеличении энергетической эффективности корма за счет применения большой процентной доли сорго и сои пути этой стабилизации видятся либо в сохранении в комбикорме постоянной, пусть невысокой, доли зерна ячменя, тритикале или пшеницы, либо в привнесении значительной доли зерна кукурузы, которая, видимо, может являться фактором сбалансированности аминокислотного состава. Третьим возможным путем может являться замена зерна колосовых злаков, снижающая энергетическую эффективность комбикорма, компонентами с лучшим балансом сырого жира по отношению к другим питательным веществам и с не меньшим, чем у них, содержанием метионина.

При сохранении высокой процентной доли в комбикорме зерна колосовых злаков потребуется присутствие стабильной доли сои для выравнивания содержания лизина и треонина, а также привнесение жиросодержащих компонентов для увеличения энергетической эффективности корма.

\section{СПИСОК ЛИТЕРАТУРЫ}

1. Афанасьева В.А. Руководство по технологии комбикормовой продукции с основами кормления животных. - Воронеж, 2007. - 385 с.

2. Доспехов Б.А. Методика полевого опыта. - М.: Агропромиздат, 1985. - 351 с.

3. Кононенко С.И. Перспективы применения сор- го в животноводстве // Научный журнал КубГАУ. 2013. - № 90. - С. 458-465.

4. Косолапов В.М., Трофимов И.А. Кормопроизводство в экономике сельского хозяйства // Вестник Российской академии сельскохозяйственных наук. 2010. - № 1. - С. 31-32.

5. Кулинцев В.В. Оптимизация аминокислотного питания молодняка сельскохозяйственных животных: дис. ... д-ра с.-х. наук. - М., 2011. - 225 с.

6. Нормы и рационы кормления сельскохозяйственных животных: справочное пособие / А.П. Калашникова [и др.]. - 3-е изд., перераб. и доп. - М., 2003. - 456 с.

7. Оптимизация полноценного кормления мясных пород крупного рогатого скота на основе использования местных кормовых ресурсов для юго-восточной микрозоны Саратовской области / С.П. Москаленко [и др.] // Аграрная наука в XXI веке: проблемы и перспективы: материалы VIII Всерос. науч.-практ. конф. - Саратов, 2014. - С. 250-253.

8. Семёнов В.В., Кононенко С.И., Кононенко И.С. Питательность и аминокислотный состав сортов зерна сорго, используемых в кормлении животных // Сельскохозяйственный журнал. - 2011. - Т. 1. - № 4-1. - С. 86-88.

9. Энергетическая эффективность экспериментальных образцов комбикорма для молодняка КРС / И.А. Кибкало [и др.] // Аграрный научный журнал. 2019. - № 12. - С. 54-60.

Кибкало Илья Анатольевич, канд. с.-х. наук, ведущий научный сотрудник отдела биохимии и биотехнологии, ФГБНУ Российский научно-исследовательский и проектно-технологический институт сорго и кукурузы «Россорго». Россия.

Каменева Ольга Борисовна, канд. с.-х. наук, главный научный сотрудник отдела биохимии и биотехнологии, ФГБНУ Российский научно-исследовательский и проектно-технологический институт сорго и кукурузы «Россорго». Россия.

Жук Екатерина Александровна, канд. с.- $x$. наук, главный научный сотрудник отдела биохимии и биотехнологии, ФГБНУ Российский научно-исследовательский и проектно-технологический институт сорго и кукурузы «Россорго». Россия.

Бычкова Вера Валерьевна, старший научный сотрудник отдела биохимии и биотехнологии, ФГБНУ Российский научно-исследовательский и проектнотехнологический институт сорго и кукурузы «Россор20». Россия.

410050, г. Саратов, 1-й Институтский проезд, 4. Тел.: (8452) 79-49-69.

ключевые слова: комбикорм; аминокислотный состав; протеин; незаменимые аминокислоты; сорго.

\section{CONDITIONALITY OF AMINO ACID COMPOSITION OF EXPERIMENTAL SAMPLES OF FEED FOR YOUNG CATTLE}

Kibkalo Ilya Anatolyevich, Candidate of Agricultural Sciences, Leading Researcher, Russian Scientific Research and Design Institute of Sorghum and Maize "Rossorgo". Russia.

Kameneva Olga Borisovna, Candidate of Agricultural Sciences, Chief Researcher, Russian Scientific Research and Design Institute of Sorghum and Maize "Rossorgo". Russia.

Zhuk Ekaterina Aleksandrovna, Candidate of Agricultural Sciences, Chief Researcher, Russian Scientific Research and Design Institute of Sorghum and Maize "Rossorgo". Russia.

Bychkova Vera Valeryevna, Senior Researcher, Russian Scientific Research and Design Institute of Sorghum and Maize
“Rossorgo”. Russia.

Keywords: feed; amino acid composition; protein; essential amino acids; sorghum.

The amino acid composition of protein in mixed feed samples of experimental formulations for young cattle is analyzed. The variation of the content of individual amino acids depending on the component composition of the feed was revealed. The possibilities of combining the high content of individual essential amino acids in one version of feed are considered. 